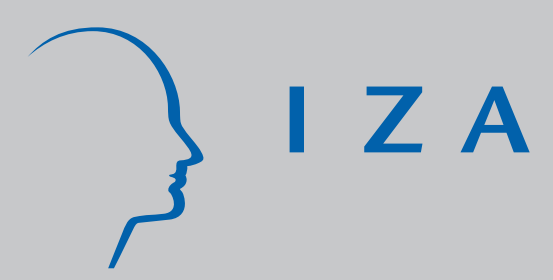

IZA DP No. 5852

Exporting Poor Health: The Irish in England

Liam Delaney

Alan Fernihough

James P. Smith

July 2011

Forschungsinstitut

zur Zukunft der Arbeit

Institute for the Study

of Labor 


\title{
Exporting Poor Health: The Irish in England
}

\author{
Liam Delaney \\ University College Dublin
}

Alan Fernihough

University College Dublin

\author{
James P. Smith \\ RAND Corporation \\ and IZA
}

\section{Discussion Paper No. 5852 \\ July 2011}

IZA

P.O. Box 7240

53072 Bonn

Germany

Phone: +49-228-3894-0

Fax: +49-228-3894-180

E-mail: iza@iza.org

\begin{abstract}
Any opinions expressed here are those of the author(s) and not those of IZA. Research published in this series may include views on policy, but the institute itself takes no institutional policy positions.

The Institute for the Study of Labor (IZA) in Bonn is a local and virtual international research center and a place of communication between science, politics and business. IZA is an independent nonprofit organization supported by Deutsche Post Foundation. The center is associated with the University of Bonn and offers a stimulating research environment through its international network, workshops and conferences, data service, project support, research visits and doctoral program. IZA engages in (i) original and internationally competitive research in all fields of labor economics, (ii) development of policy concepts, and (iii) dissemination of research results and concepts to the interested public.
\end{abstract}

IZA Discussion Papers often represent preliminary work and are circulated to encourage discussion. Citation of such a paper should account for its provisional character. A revised version may be available directly from the author. 
IZA Discussion Paper No. 5852

July 2011

\section{ABSTRACT}

\section{Exporting Poor Health: The Irish in England ${ }^{*}$}

The Irish-born population in England is in worse health than both the native population and the Irish population in Ireland, a reversal of the commonly observed healthy migrant effect. Recent birth-cohorts living in England and born in Ireland, however, are healthier than the English population. The substantial Irish health penalty arises principally for cohorts born between 1920 and 1960. This paper attempts to understand the processes that generated this migrant health pattern. Our results suggest a strong role for early childhood conditions and economic selection in driving the dynamics of health differences between the Irish-born migrants and White English populations.

JEL Classification: J60

Keywords: healthy migrants, mental health, migrant selectivity

Corresponding author:

James P. Smith

RAND

1776 Main Street

P.O. Box 2138

Santa Monica, CA 90407

USA

E-mail: smith@rand.org

\footnotetext{
* Thanks to Christian Danne and Iva Maclennan for excellent research assistance. Delaney acknowledges generous support from the Fulbright Commission and the Center for Health and WellBeing, Woodrow Wilson School, Princeton University. RAND research was funded from a grant by NIA.
} 


\section{Introduction}

Migration research has traditionally examined the relative role of selectivity of migrants including their health, as well as impacts of acculturation into the receiving country on migrant health (Jasso et al., 2004). This research has emphasized the 'healthy’ migrant effect pointing out that on average migrants are healthier than populations in sending countries from which they are drawn. This research also argued that migrants often move to countries where either the stress of migrating to a new land or health behaviors may be worse than in the sending countries so that the health advantage of migrants dissipates over time. Both in terms of selectivity and acculturation effects, the economics literature has focused almost exclusively on physical health issues. Far less research exists explaining the extent to which migration influences mental health, as well as how psychological health influences initial migration selection. In this paper, we examine the economics of a case where selectivity of migrants appears to be very negative and mental health issues are at least as important as physical health concerns.

This paper examines health and psychological well-being of Irish immigrants in England in the $20^{\text {th }}$ century. Historical interactions between Ireland and England underwent several shifts during the $20^{\text {th }}$ century that changed incentives to migrate and composition of flows. The countries are geographically proximate and England represented the main destination country for Irish migrants in the $20^{\text {th }}$ century. Irish migrants to England had well-documented physical and psychological health problems. This paper aims to understand these problems in the context of an economic model of selection and assimilation. While the US was the main destination for Irish migrants in the $19^{\text {th }}$ century, England was the overwhelming destination of choice of Irish migrants and remained so for much of the 20th century.

In general, our data point to an Irish population in England being less healthy both in physical and mental health than both the native born English and Irish populations. However, 
this masks substantial heterogeneity. The pre-1920 Irish birth cohort were slightly healthier, the birth cohorts between the 1920s and 1960s were markedly less healthy and recent migrants are significantly healthier than comparable native English and Irish populations. Understanding these patterns can reveal a lot about processes linking early life conditions, migration, adverse conditions experienced in destination countries and later life health.

If Irish migrants were randomly selected from the Irish population and their health did not suffer from living in England, health differences between the Irish migrant and English populations would only reflect differences between the native-born Irish and native-born English population. Health differences between migrants and native populations arise for two main reasons; migrants experience more stressful conditions in the destination country that may lead to worse health, and second migrants select themselves to destinations based on a bundle of characteristics including health. Irish migrants living in England throughout most of the $20^{\text {th }}$ century lived through many periods of political stress and occasional violence between the two countries which may have affected their mental health. On the other hand, conditions in Ireland for some children were by no means stress free and a disproportionate fraction of such children may appear to have migrated to England. Our analysis uses a combination of micro-survey data collected in England in the late 1990s and early part of the current decade combined with a comparable data-set surveying the Irish population in Ireland from the same period. ${ }^{1}$

The remainder of this paper is structured as follows. Section 2 outlines the background to Irish migration in the 20th century, providing figures on the numbers of migrants and the current stock. It also reviews prior knowledge of the health patterns of the Irish in the UK and their descendents. Section 3 outlines data utilized in this study, describing the nature and

\footnotetext{
${ }^{1}$ We examine the Irish population in England due to data limitations. But this represents a large majority of the Irish-UK population. Of the 390,000 Irish estimated to be in the UK in 2009, over 330,000 are in England.
} 
comparability of key variables. Section 4 discusses theoretical considerations of the impact of migration on subsequent health providing descriptive and econometric analysis of the health of successive cohorts of Irish migrants in England. We compare the health of birth migrant birthcohorts to that of the native White English born population and the Irish population in Ireland. We then study potential selection effects by examining the height and education of the migrants, on the assumption that these variables are determined prior to migration. Section 5 investigates the extent to which assimilation may have generated Irish migrant health patterns using length of time spent in England as an exposure variable. Section 6 concludes with implications for our understanding of both the health of Irish migrants of the Irish aging population more generally.

\section{Background and Literature}

\subsection{Background of Irish Migration to England}

Figure 1 depicts the extent of post first world war net migration in Ireland which was predominately a net outflow flow from Ireland. Britain was the major destination country for most of the post-1940s migrants. A report by NESC (1991), estimates that Britain accounted for $79 \%, 86 \%$ and $54 \%$ of the migration outflows in the 1946-51, 1971-81 and 1981-90 periods, respectively. The 2001 UK Census enumerated 460,287 Irish born in England, a figure that represents a sizeable proportion, $13.5 \%$, of the total Irish born population in Ireland. ${ }^{2}$

Several studies, such as O' Grada and Walsh (1994) and Kearney (1998), examine macroeconomic determinants of $20^{\text {th }}$ century Irish migration. The results of these time-series econometric models are consistent; a close link existed in relative differences between Irish and British labor markets. The National Economic and Social Council's 1991 report, entitled "The Economic and Social Implications of Emigration,” provides a useful evaluation of 20th century

\footnotetext{
${ }^{2}$ Irish and UK censuses. The number of Irish people living in England declined from 2001 to 2010. The 2010 population figures list 398,000 Irish-born people living in the UK.
} 
dynamics in the Irish migrant cohort's age, socio-economic, gender and other characteristics. The post-WW2 pre-1980s cohort was typically young, unskilled and from economically underdeveloped regions of Ireland. This profile began to change in the late 1970s to a higher educated, more skilled group from a wide spectrum of Irish regions. As documented in O’Grada and Walsh (1994), the 1960s and 1970s marked a period of relative wage convergence between the Republic of Ireland and Britain.

\section{Figure 1. Annual Estimates of Net Migration from Ireland (000s)}

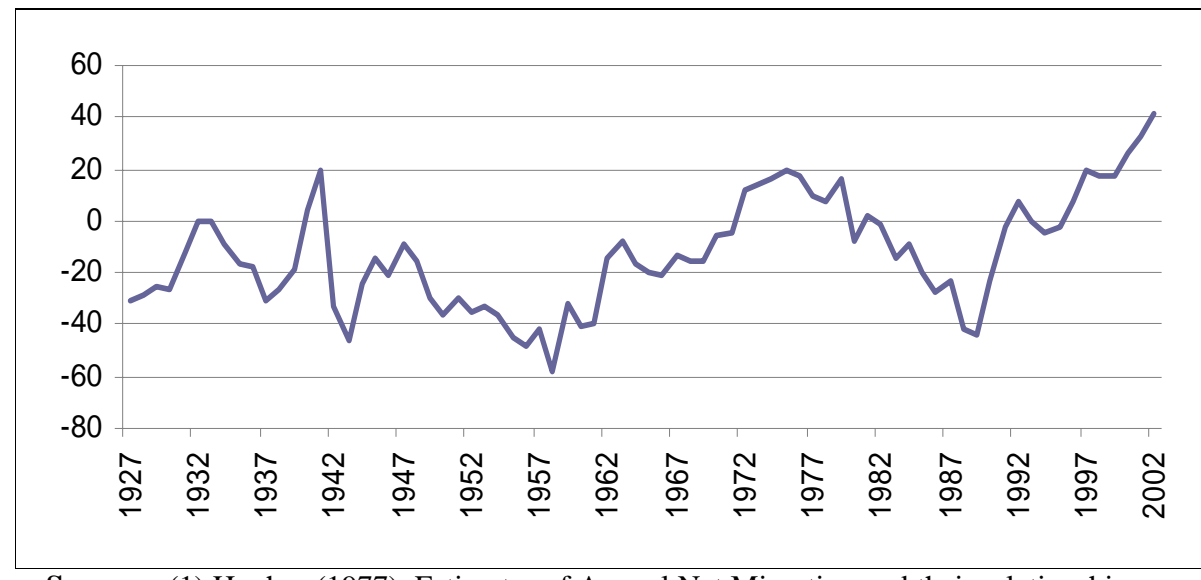

Sources: (1) Hughes (1977), Estimates of Annual Net Migration and their relationship with Series on Annual Net Passenger Movement; Ireland 1926-1977. ESRI Memorandum Series No. 122. (2) Central Statistics Office, Dublin.

\subsection{Literature on Health of Irish Migrants in the UK}

The epidemiology and public health research consistently finds Irish migrants to be in worse health compared to their British counterparts. Mortality is the most commonly used barometer of health of the Irish population in the UK. The OPCS Mortality and Geography review in the 1980s reported high mortality rates amongst both Irish men and women in both 2049 and 20-69 age cohorts. In fact, the Irish had the highest mortality rates of all groups in this study, excluding African women in the 20-49 age category. Marmot et al. (1984) analyzed the mortality disparity between the Irish and the English and Welsh. After controlling for socioeconomic status, Irish men still have higher mortality rates. 
Researchers have observed trends within illness patterns of Irish migrants. Raftery et al. (1990) highlight comparatively high death rates from accidents, poisoning and violence in this group. Adelstein et al. (1986) examined standard mortality ratios (SMRs) and shows that Irish migrant health patterns are not typical of the Irish population in Ireland. Their data indicated that the Irish migrant group had comparatively high SMRs for certain conditions where some element of behavior is likely to be a causal factor.

Several researchers explored mental well-being of the Irish in Britain. Cochrane (1983) highlights the large proportion of Irish seeking hospital consultations for issues of mental health. Aspinall (2002) provides further insight evaluating the high suicide rates amongst the Irish migrants. Leavey (1999) and Maxwell and Harding's (1998) findings, that adjusting for social class explains virtually none of the excess suicide rate amongst men, are noted. Leavey et al. (2007) analyzed the Irish in the UK’s mental health. The authors employ qualitative research method design and conduct interviews on Irish migrants, some suffering from depression, to explore the reasons for psychological distress. They report a strong likelihood that the root of physiological distress is established in the pre-migration period.

While health disadvantages of Irish migrants to England are well-documented, there is little agreement on the source of these disadvantages and reason for the heterogeneity. Studying Irish migrant populations in England offers an opportunity to understand the role of changing selection, assimilation, and mental health in generating migrant health differences over time. Our study is the first to use representative data from the Irish-born and White English in England, and the Irish population in Ireland to examine roles of selection and assimilation. 


\section{Data and Descriptive Statistics}

We use the micro data from the 1998, 1999 and 2004 Health Survey for England (HSE) surveys to examine the health status trajectories of the Irish born population in England. Wave 7, surveyed in 2000, of the Living in Ireland Survey is employed to include the Irish born in Ireland population in our analyses.

\subsection{The Health Survey for England (HSE)}

The HSE is an annual survey designed by the Department of Health aimed at monitoring demographic health trends for the English population. Questionnaires from the survey are largely consistent from year to year, enabling us to append survey years thereby obtaining larger crosssections of data. Each year incorporates a different theme designed to address a specific issue. In 1998, the HSE was based on examining the prevalence of cardio-vascular disease in England, while the 1999 and 2004 surveys focused on the health of minority ethnic groups. These surveys are chosen for our pooled cross-section of data because they enumerate the participant's country of birth, which is not available in any other survey years.

We compose our working data sample by combining the 1998, 1999 and 2004 data samples. We take the Irish born population from each of the surveys. The White English born population sample is obtained from the 1998 survey. The 1998 survey was the closest survey, to the 1999 and 2004, simultaneously asking both country of birth and ethnicity. In addition, the indigenous English population is not present in the 1999 and 2004 surveys and there is no clear way of identifying this group in other surveys.

Key demographic characteristics, age, sex, and marital status, exist in all surveys. Years in full time education is computed from respondents answer to the question about age they left full time education. The results displayed in Appendix Table 1 are based on several assumptions. 
We assume that everybody begins school at age 5; that those who finished school at '19 or over' completed some higher-level diploma and received 3 years post-secondary schooling; that those who left school '14 and under' left at age 12 (seven years of schooling).

\subsection{Living in Ireland (LII)}

Micro-data from wave 7 of the Living in Ireland (LII) survey, part of the European Community Household Panel survey conducted in 2000, are used to examine the domestic population of Irish non-migrants. ${ }^{3}$ All non-Irish born are excluded from our sample, resulting in 7,883 observations. Wave 7 of the LII panel collects a number of variables that allow us to examine key differences between the Irish born populations in both Ireland and England. The LII survey design is similar to the HSE. Both surveys are conducted by personal interview, contain common demographic variables, and are nationally representative. In addition, the LII wave we use, 2000, was conducted at a similar time to the HSE micro-data sets we use. Both the LII and HSE surveys are nationally representative samples of both the Irish and English household population. Some variables from LII have been rectified for data comparability issues. We construct a cardinal measure of education based on the highest level of education completed. This data are based upon the assumption that all children enter school at age $5 .{ }^{45}$

\subsection{Basic Health Differences}

Basic health disparities are displayed in Figure 2 which plots the fraction in poor health by birth cohort for three groups- the Irish born living in England, the Irish born living in Ireland, and the White English. A substantially higher proportion of the Irish living in England is in poor health, compared to the Irish in Ireland or the White English population. The fact that the Irish in Ireland

\footnotetext{
${ }^{3}$ This cohort contains return migrants, whom we classify as non-migrants.

${ }^{4}$ We correct for participants stating "no education," by using the "how old were you when you completed this," question. Appendix Table 2 displays participants in no education category who have some formal schooling.

${ }^{5}$ HSE measures heights objectively. LII survey asks participants their stature. To address this problem, we use data from Irish Universities Nutrition Alliance study, which measured Irish heights. Mean heights are very similar to LII.
} 
are in better health is in line with a long literature that finds that people in the Republic of Ireland have among the highest self-rated health scores in the world (e.g., Carlson, 1998; Delaney, OhAodha and Wall, 2007). Figures 2b and 2c look at disparities further for men and women. As can be seen, outcome differences are particularly accentuated for men, though Irish women migrants also have a health penalty relative to those in Ireland and the White English sample.

Figure 2a. Proportion in Bad Health by Cohort

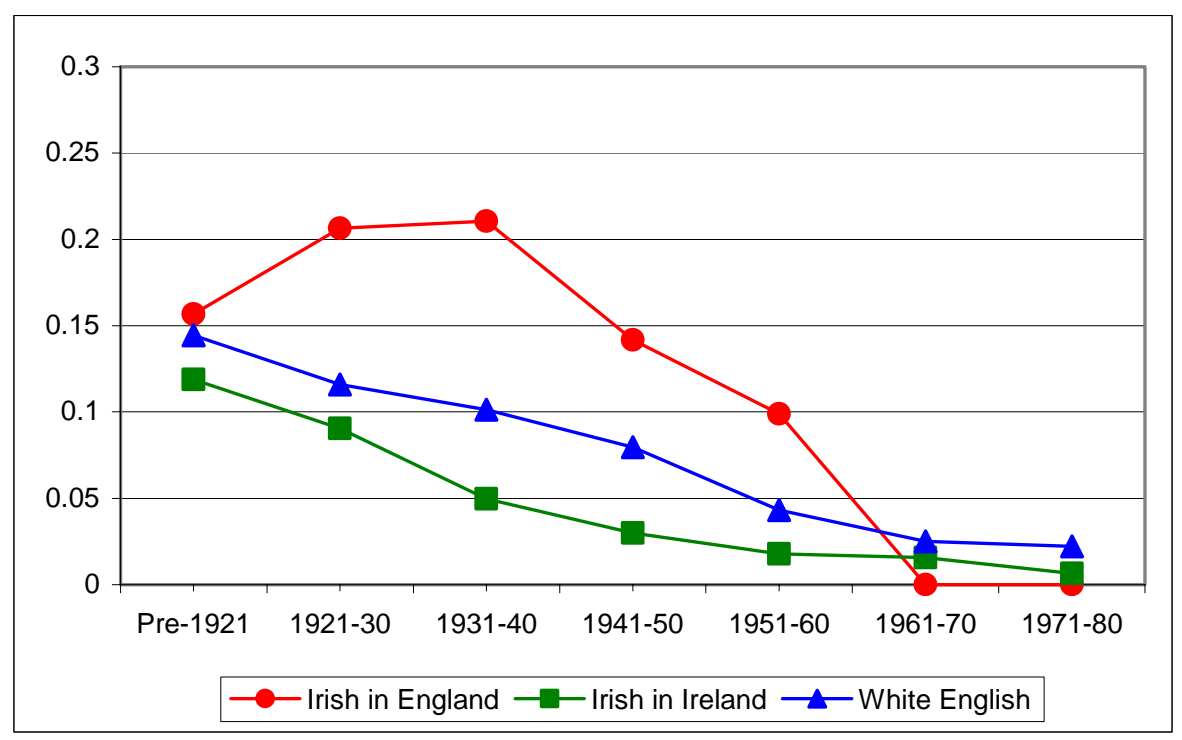

Sources: HSE 1998, 1999 and 2004 \& Living in Ireland 2000.

Figure 2 also highlights considerable heterogeneity in these health disparities by birth cohort. The poor health excess of the Irish in England compared to the two other groups is particularly large for the birth cohorts born between 1921 and 1960, but is smaller for the pre1921 birth cohort and the more recent post 1960 birth cohorts. Explaining this heterogeneity in the heath penalty for the Irish in England is a major aim of this paper. 
Figure 2b. Proportion of Men in Bad Health

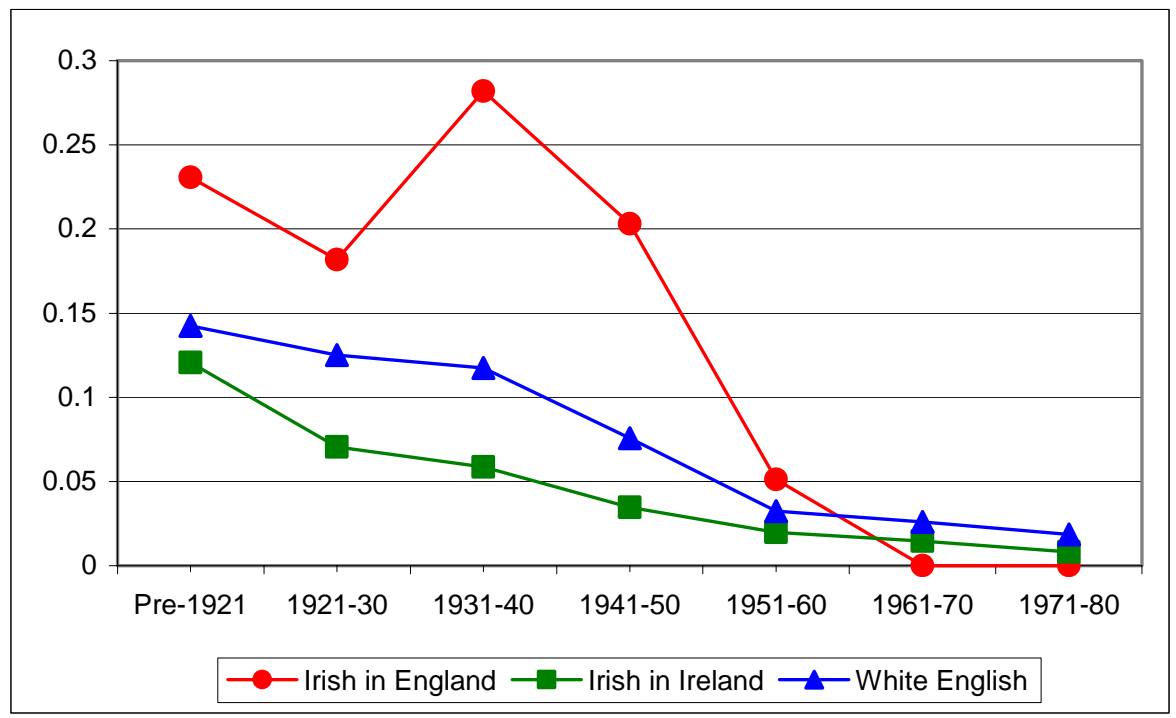

Sources: The HSE 1998, 1999 and 2004 \& Living in Ireland 2000.

Figure 2c. Proportion of Women in Bad Health

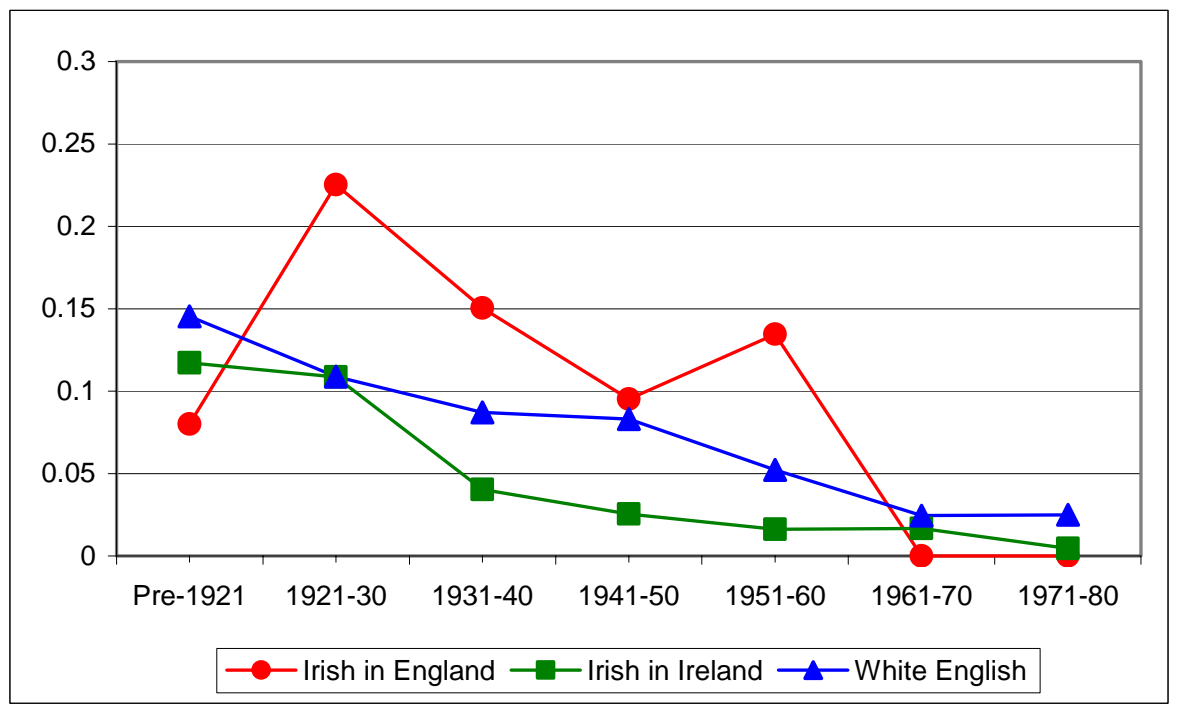

Sources: The Health Survey for England 1998, 1999 and 2004 \& Living in Ireland 2000.

Explaining mental health disparities is another central theme of this paper. Figure 3 displays scores on the GHQ-12 psychological distress scale for men where most of the Irish in England excess mental health illness lies. The General Health Questionnaire is a 12 question scale based on factors such as concentration, losing sleep, confidence, under strain, feeling depressed, happy, worthless, self-perceived capability, etc. that has been favorably tested for 
reliability and validity (Goldberg et al., 1970 and Hannon, 1970). For each of the 12 questions, responses are measured on a Likert scale and can score anything from 0 to 3 (not at all, no more than usual, rather more than usual, much more than usual). Total score is then summed across the 12 questions. The male Irish-born migrant sample display substantially higher levels of psychological distress than the Irish native sample and higher, though less dramatically so, levels of psychological distress than the UK sample. These excess mental health problems are concentrated in the 1931-1950 birth cohorts.

Figure 3. Male Psychological Distress Scores (GHQ-12)

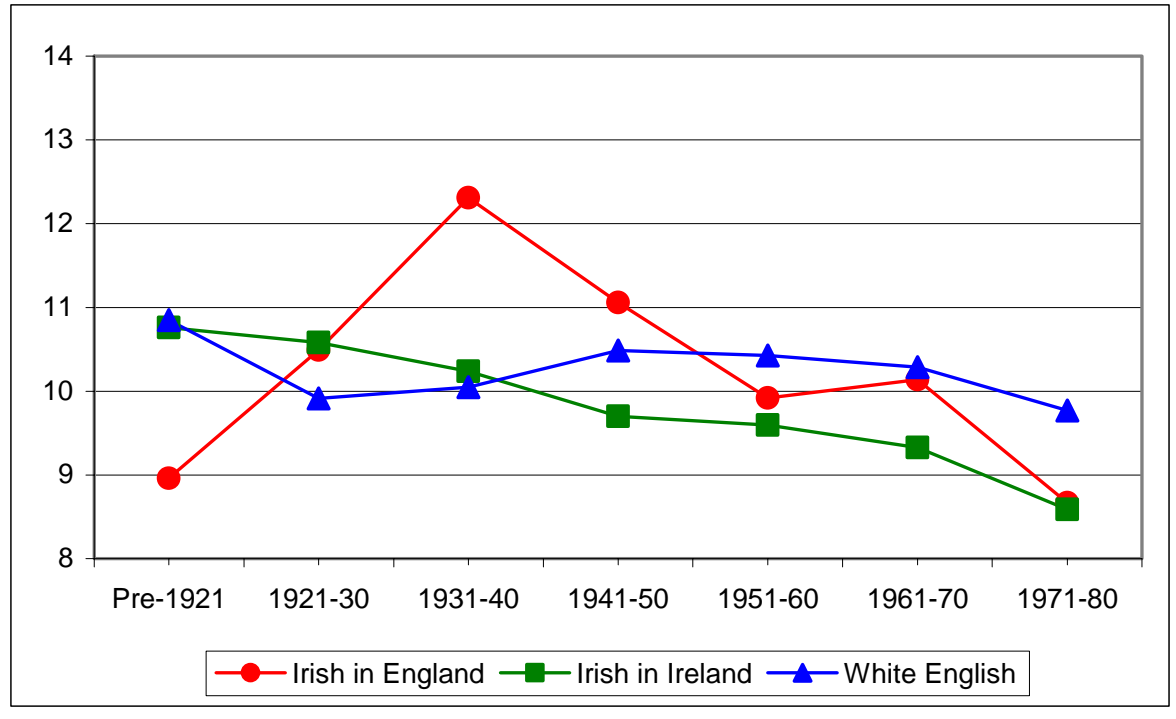

To set the stage for analyses to follow, Table 1 displays a set of OLS models describing birth cohort variation in various health measures in the HSE for Irish born and native-born English residents. Our health measures include the probability the respondent is in good health (very good or good), in bad health (bad or very bad), and whether a respondent reports three specific types of physical illnesses—cardiovascular disease, muscular disease, and respiratory disease. Besides a set of ten year birth cohort dummies (born pre-1921 the excluded group) to test for patterns of health differentials between the Irish and English groups in England, we 
interacted three birth cohort groups with being Irish born-born pre-1921, born between19211960 and born between 1961-1980.

Table 1: OLS Regression from the Pooled HSE (living in England)

\begin{tabular}{lccccc}
\hline Variables & $\begin{array}{c}(1) \\
\text { Good health }\end{array}$ & $\begin{array}{c}(2) \\
\text { Bad health }\end{array}$ & $\begin{array}{c}(3) \\
\text { cardio }\end{array}$ & $\begin{array}{c}(4) \\
\text { muscular }\end{array}$ & $\begin{array}{c}\text { (5) } \\
\text { respiratory }\end{array}$ \\
\hline male & & & & & \\
& -0.0019 & 0.0030 & 0.0076 & -0.0070 & 0.0019 \\
Irish Born pre-1921 & -0.0069 & -0.0040 & -0.0069 & -0.0063 & -0.0048 \\
& 0.0563 & 0.0238 & -0.0421 & 0.0642 & $-0.0733^{*}$ \\
Irish Born 1921-60 & -0.0629 & -0.0367 & -0.0625 & -0.0569 & -0.0435 \\
& $-0.112^{* * *}$ & $0.0877^{* * *}$ & $0.0455^{* *}$ & -0.0018 & 0.0209 \\
Irish Born 1961-80 & -0.0194 & -0.0113 & -0.0192 & -0.0175 & -0.0134 \\
& $0.104^{* * *}$ & -0.0263 & -0.0040 & -0.0351 & $-0.0525^{* *}$ \\
Born 1921-30 & -0.037 & -0.0216 & -0.0367 & -0.0334 & -0.0256 \\
& 0.0251 & -0.0060 & $0.0498^{* * *}$ & 0.0076 & $-0.0233^{* *}$ \\
Born 1931-40 & -0.0165 & -0.00965 & -0.0164 & -0.0149 & -0.0114 \\
& $0.0809^{* * *}$ & $-0.0179^{*}$ & $-0.0398^{* *}$ & -0.0111 & $-0.0376^{* * *}$ \\
Born 1941-50 & -0.0158 & -0.0092 & -0.0157 & -0.0143 & -0.0109 \\
& $0.158^{* * *}$ & $-0.0429^{* * *}$ & $-0.189^{* * *}$ & $-0.0937 * * *$ & $-0.0567^{* * *}$ \\
Born 1951-60 & -0.0152 & -0.0090 & -0.0151 & -0.0137 & -0.0105 \\
& $0.238^{* * *}$ & $-0.0776^{* * *}$ & $-0.313^{* * *}$ & $-0.164^{* * *}$ & $-0.0470^{* * *}$ \\
Born 1961-70 & -0.0151 & -0.0088 & -0.015 & -0.0136 & -0.0104 \\
& $0.274^{* * *}$ & $-0.0923^{* * *}$ & $-0.358^{* * *}$ & $-0.189 * * *$ & $-0.0517^{* * *}$ \\
Born 1971-80 & -0.0148 & -0.0086 & -0.0147 & -0.0134 & -0.0102 \\
& $0.261^{* * *}$ & $-0.0992^{* * *}$ & $-0.390^{* * *}$ & $-0.242^{* * *}$ & $-0.0216^{* *}$ \\
Constant & -0.0157 & -0.0092 & -0.0156 & -0.0142 & -0.0109 \\
& $0.570^{* * *}$ & $0.120^{* * *}$ & $0.496^{* * *}$ & $0.315^{* * *}$ & $0.135^{* * *}$ \\
Observations & -0.0129 & -0.0075 & -0.0128 & -0.0116 & -0.0089 \\
R-squared & & & & 15,471 & 15,471 \\
\hline
\end{tabular}

Standard errors in parentheses- ${ }^{* * *} \mathrm{p}<0.01,{ }^{* *} \mathrm{p}<0.05$, ${ }^{*} \mathrm{p}<0.1$.

Sources: Health Survey for England 1998, 1999 and 2004. sample is Irish and English in England

Since earlier born cohorts are older in any calendar year, earlier born cohorts are characterized as being in poorer health in all our health measures. More important, our estimates indicate a statistically significant and substantial .pattern of excess poor health for those Irish born between 1921 and 1960 and who were living in England. With regard to specific health conditions, this Irish born group report a statistically significantly higher probability of having a cardiovascular condition though neither muscular nor respiratory conditions, suggesting that stress and inflammation may play a role in this excess illness. When we estimated separate 
models for men and women, we found excess poor health in good, bad, and cardiovascular health for men and women although the effects were larger for men than women.

To test health differences between the Irish born who live in England and those who stayed in Ireland, Table 2 combines samples of Irish born in the HSE and the Living in Ireland surveys. Once again, among Irish born in the 1921-1960 birth cohorts, we find a statistically significant and substantial pattern of excess poor health and a greater degree of mental problems among those Irish born who migrated to England compared to the Irish born who stayed in Ireland.. When we estimated separate models by gender, the excess poor subjectively reported health for the Irish Born 1921-1960 was about the same for men and women, but the worse mental health for these birth cohorts was concentrated on men only.

Table 2

\section{Comparing the Irish in England to the Irish in Ireland}

(2)

(3)

\begin{tabular}{|c|c|c|c|}
\hline Variables & Health Good & Health Bad & iHQ score \\
\hline \multirow[t]{2}{*}{ Male } & -0.0036 & 0.0028 & -0.611 \\
\hline & -0.0089 & -0.0044 & -0.11 \\
\hline \multirow[t]{2}{*}{ Irish Born pre-1921 } & $0.204^{* * *}$ & -0.0190 & -2.30 \\
\hline & -0.0647 & -0.0320 & $-0.77 i$ \\
\hline \multirow[t]{2}{*}{ Irish Born 1921-60 } & $-0.144 * * *$ & $0.132 * * *$ & 0.681 \\
\hline & -0.0224 & -0.0111 & $-0.26 !$ \\
\hline \multirow[t]{2}{*}{ Irish Born 1961-80 } & 0.0419 & -0.0114 & 0.66 \\
\hline & -0.0426 & -0.0210 & -0.501 \\
\hline \multirow[t]{2}{*}{ Born 1921-30 } & $0.126^{* * *}$ & $-0.0302 * *$ & $-0.61 !$ \\
\hline & -0.0276 & -0.0136 & -0.351 \\
\hline \multirow[t]{2}{*}{ Born 1931-40 } & $0.217 * * *$ & $-0.0675 * * *$ & $-1.43 !$ \\
\hline & -0.0266 & -0.0131 & -0.34 \\
\hline \multirow[t]{2}{*}{ Born 1941-50 } & $0.322^{* * *}$ & $-0.0892 * * *$ & $-1.73 !$ \\
\hline & -0.0258 & -0.0127 & $-0.33^{\prime}$ \\
\hline \multirow[t]{2}{*}{ Born 1951-60 } & $0.388^{* * *}$ & $-0.101 * * *$ & -1.82 \\
\hline & -0.0257 & -0.0127 & $-0.33 !$ \\
\hline \multirow[t]{2}{*}{ Born 1961-70 } & $0.422^{* * *}$ & $-0.103^{* * *}$ & -1.991 \\
\hline & -0.0262 & -0.0130 & -0.34 \\
\hline \multirow[t]{2}{*}{ Born 1971-80 } & $0.462 * * *$ & $-0.112 * * *$ & $-2.87 !$ \\
\hline & -0.0257 & -0.0127 & $-0.33 !$ \\
\hline \multirow[t]{2}{*}{ Constant } & $0.473 * * *$ & $0.118^{* * *}$ & 12.03: \\
\hline & -0.0239 & -0.0118 & -1 \\
\hline Observations & 7352 & 7352 & \\
\hline R-squared & 0.106 & 0.048 & ( \\
\hline
\end{tabular}


The results in Tables 1 and 2, which document excess poor health among Irish migrants to England born between 1921-1960, cannot speak to reasons for this health penalty- how much can be attributed to migration selection and how much to factors associated with assimilation into England. We deal with those issues in the next sections.

\subsection{Health Selection -Basic Selection Markers}

The foremost issue when accounting for the Irish migrant health penalty is how much is driven by selection factors versus assimilation factors. To distinguish between them, we evaluate the impact of pre-migration and post-migration factors on health status of these groups. We use educational attainment and adult height as our markers of pre-migration selection factors. To make sure our comparisons reflect conditions in Ireland and not in England, it is worth considering Irish migrants who may have completed some form of schooling in England. The 1999 and 2004 HSEs contain data on year of migration. We assume that the individual received some form of education in England if their years of education variable exceeds the age at which they migrated minus five, essentially assuming that individuals commence schooling at five. Employing this method on the 1999 and 2004 sub-samples shows us that 152 of the 655, or 23\% of Irish migrants received some form of education in England. Therefore, in all our analysis in this paper, we use a sample of individuals educated exclusively in Ireland to compare on this premigration characteristic across cohorts. Given this algorithm, the heights of our sample of Irish migrants were also determined by pre-migratory conditions in Ireland.

Figure 4.a shows our comparisons for education by birth cohort for the white English, the Irish born living in England and the Irish living in Ireland while 4.b and 4.c repeats this comparison for men and women separately. Especially in the birth cohorts between 1930 and 
1960, the English are more educated than either of the two Irish comparison groups while the Irish in Ireland are more educated than the Irish in England. The latter comparison indicates clear negative selectivity of Irish migrants to England during this period. However, in more recent cohorts not only have the Irish in Ireland erased their education gap with the English, the sign of the selectivity of Irish migrants has reversed with Irish migrants to England now being more educated than the Irish born who stayed at home. This comparison also slightly reverses in the oldest cohort in the figure, a result that may be a combination of mortality selection among less educated Irish migrants in England or the selectivity of return migration back to Ireland.

Figure 4a. Mean Years of Full-Time Education

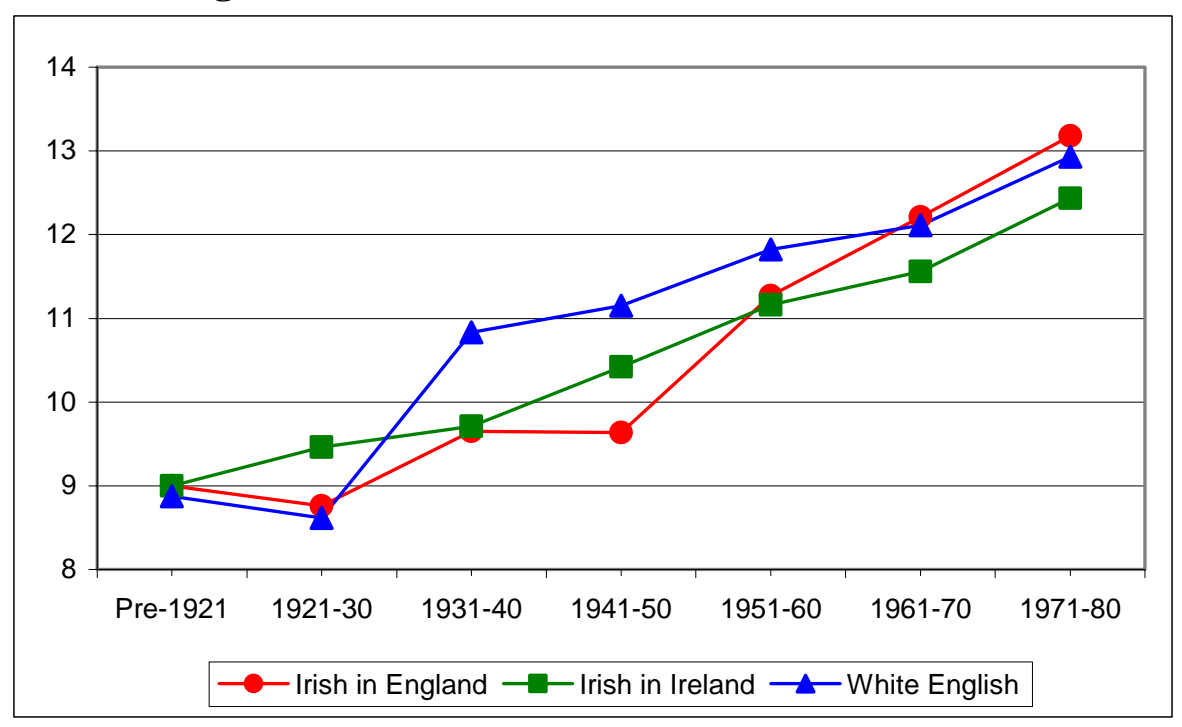

Sources: The Health Survey for England 1998, 1999 and 2004 \& Living in Ireland 2000.

When we turn to the gender specific education comparisons, we see that the general patterns are similar for men and women. However, the magnitude of the negative migration selection of Irish migrants appears to be stronger for men compared to women. At the peak of the negative education selection of Irish migrants during the 1940s, the size of the selection effect is more than a year from men, twice the rate displayed among women. 
Figure 4b. Mean Years of Education (Males)

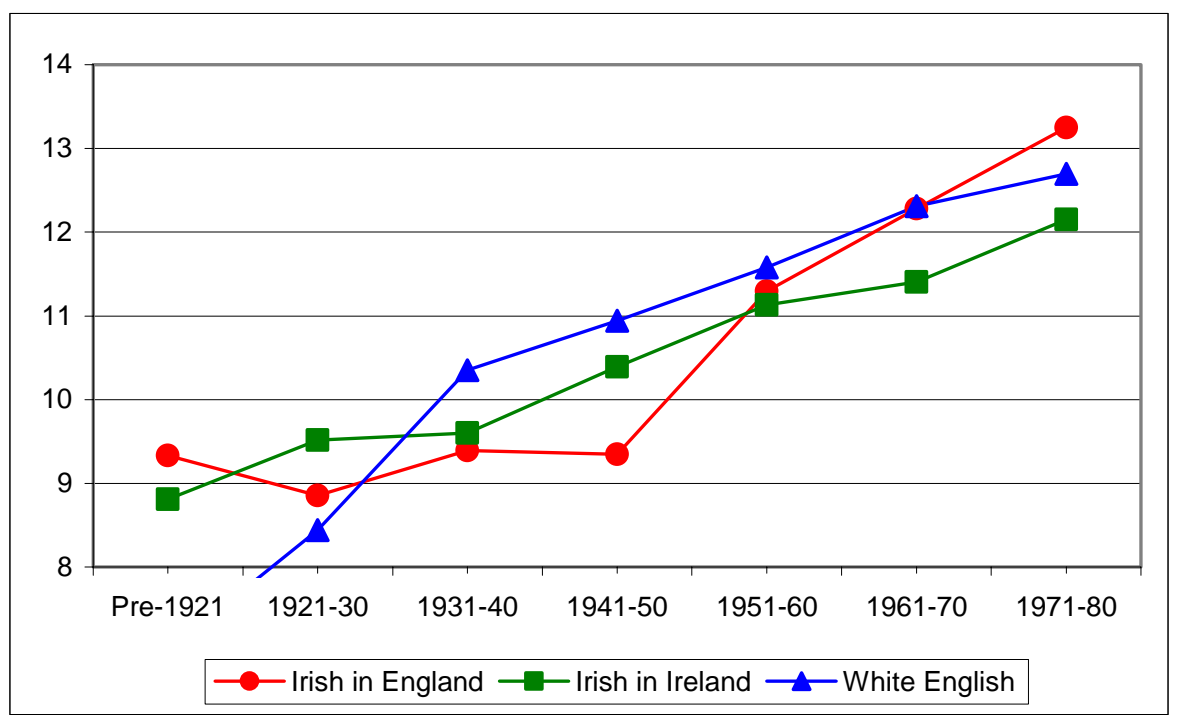

Figure 4c. Mean Education Females

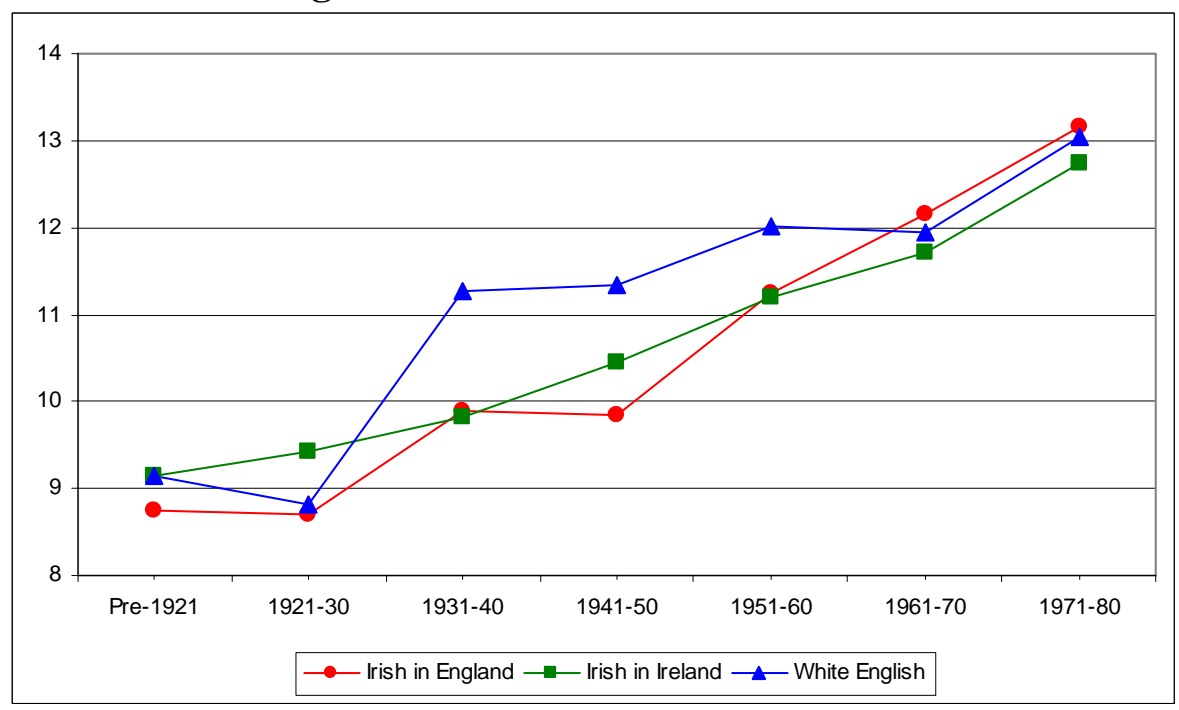

Sources: The HSE 1998, 1999 and 2004 \& Living in Ireland 2000.

Figures 5.a (for men) and 5.b (for women) display cohort differences between these groups in height in centimeters. A similar pattern is found. Between 1930 and 1970, the English are taller than either Irish comparison group but Irish migrants are shorter than Irish stayers. Height selection has reversed in the most recent cohort as migrants are now the taller of the two Irish sub-groups. Height selection appears to be about as large for women as men. 
Figure 5a. Mean Male Heights (cms)

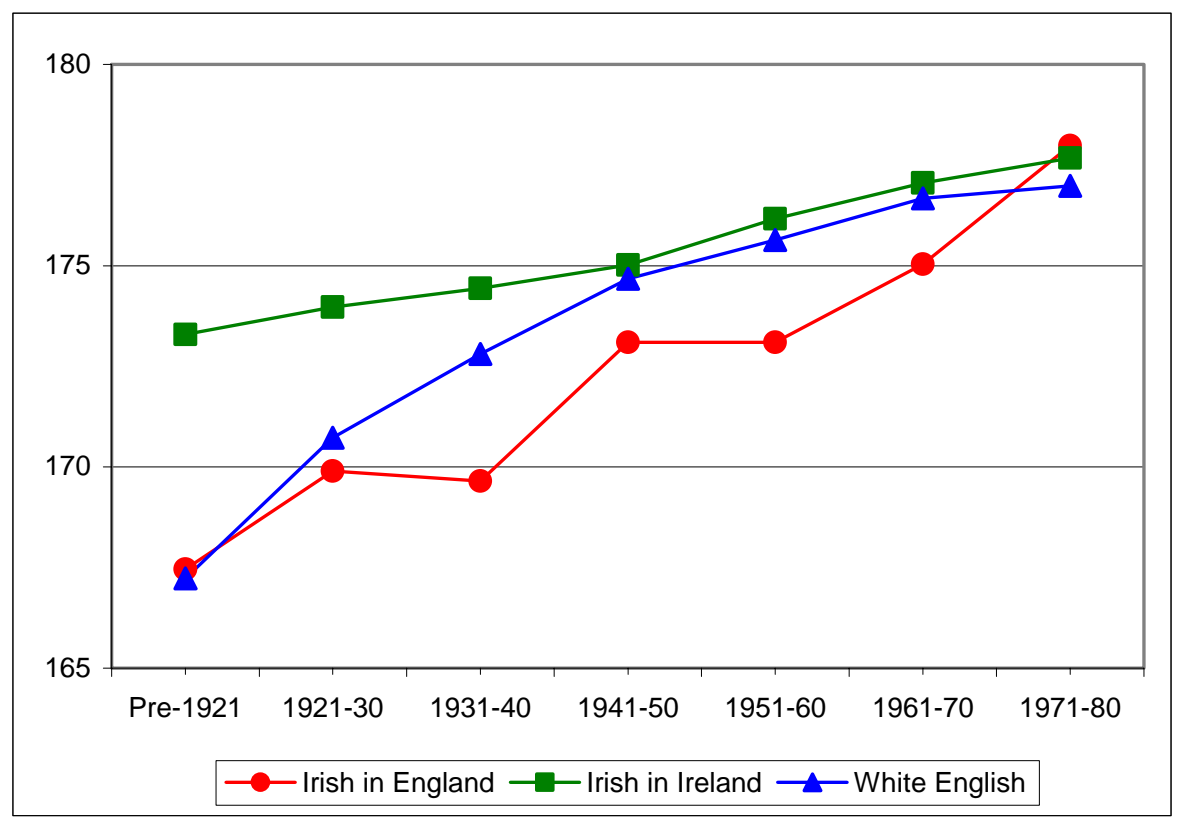

Sources: The HSE 1998, 1999 and 2004 \& Living in Ireland 2000.

Figure 5b. Mean Female Heights (cms)

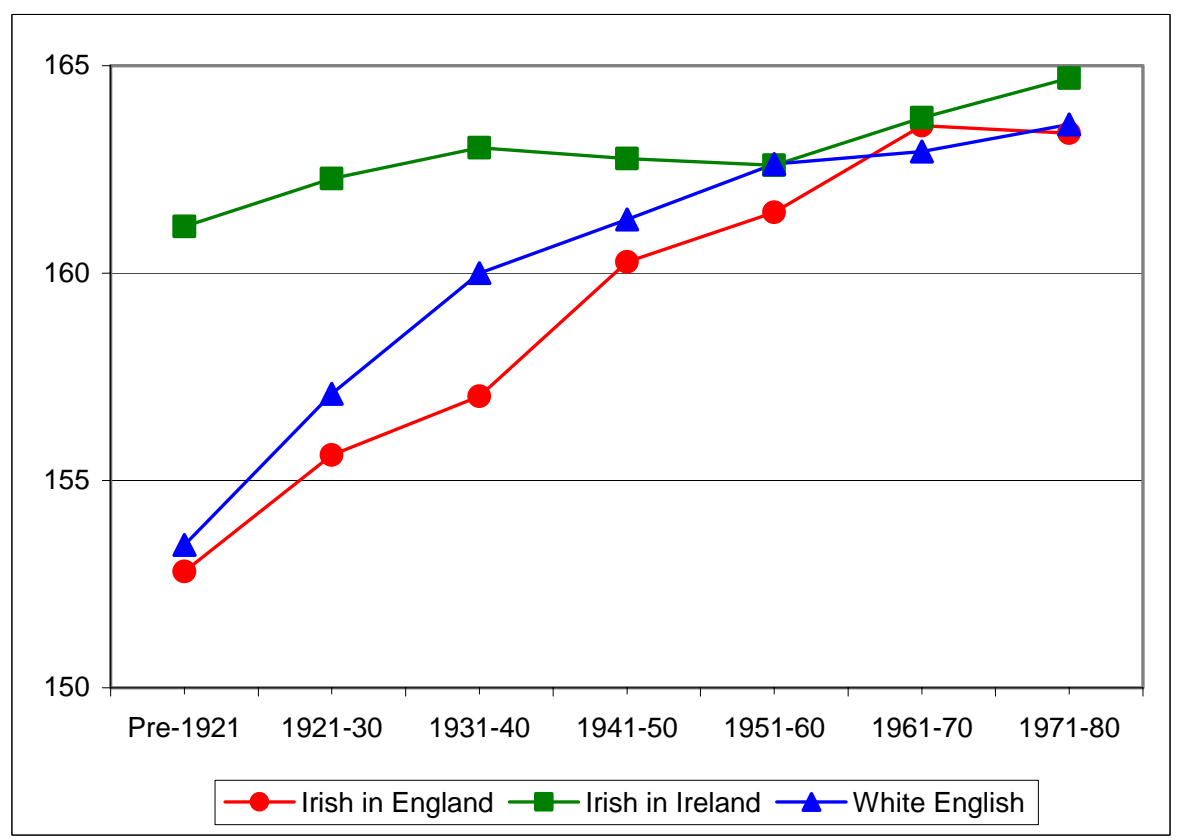

Sources: The Health Survey for England 1998, 1999 and 2004 \& Living in Ireland 2000. 


\subsection{Modeling Selection: Theoretical Model}

This section explores mechanisms producing heterogeneous migration selection and examines relationships between selection and health. Our theoretical framework is adapted from Jasso, Massey, Rosenzweig and Smith (2004). At the most general level, a migration decision is based upon the relative streams of utility, where utility is a function of an individual's consumption. Thus, i will migrate from $H$ (the home country) to $A$ (the potential migration destination) when:

$$
\text { (1) } u\left(c_{i A}\right)-\theta_{i}>u\left(c_{i H}\right)
$$

where $u\left(c_{i A}\right)$ and $u\left(c_{i H}\right)$ are utilities individual $\mathrm{i}$ would receive in the two locations and $\theta_{i}$ represents the dis-utility, or utility from migration. $\theta_{i}$ can include pecuniary components, such as travel expenses, and non-pecuniary costs, such as the psychic costs associated with moving away from family and social networks or psychic costs of remaining in the original location. We simplify this model by assuming that individual i consumes all of their income, denoted $y_{i}$. We define the income production function to be the product of i’s human capital $(k)$, labor supply $(l)$, and the relative location-specific wage rates (w). Hence, equation (1) can be re-written:

$$
\text { (2) } w_{A} k_{i A} l_{i A}-w_{H} k_{i H} l_{i H}>\theta_{i}
$$

where wage levels or skill prices $(w)$, human capital utilization $(k)$ and the labor supply relationship (l) for individual i differs based on location.

Wage levels, human capital utilization and labor supply are correlated across the two countries, $H$ and $A$. Cross-country wage rate, human capital and labor supply relationships are

(3) $w_{A}=\beta_{0}+\beta_{A} w_{H}$

where (3) describes the relation between wages in the home and away country. To justify economic migration typically $\beta_{0}$ will be positive. $\beta_{\mathrm{A}}$ measures a relative skill price premium 
between home and away country.. If wages of unskilled are relatively high in the receiving country, $\beta_{A}>1$

$$
\text { (4) } k_{i A}=\alpha_{H} \cdot k_{i H}
$$

where (4) describes the relation between human capital $(k)$ in away and home country. Non transferability of skill (say lawyers) suggests than $a_{H}$ is less than 1 while $\alpha_{H}>1$ would indicate that migrants' human capital is more relevant in the receiving country than the home country (e.g., someone trained in computer technology when there is no industry in the home country).

$$
\text { (5) } l_{i A}=c_{H} \cdot l_{i H}
$$

where (5) measures the relation between labor supply in the away and home country. If $c_{H}>1$, then a migrant would work more in the away country than in the home country. This would be the case if unemployment is high in the home country. Substituting (3), (4) and (5) into (2) gives $w_{A} k_{i H} l_{i H}\left(\alpha_{H} c_{H}+\frac{\beta_{0}}{w_{A}}+\beta_{H}\right)>\theta_{i}$

This provides us with several insights into selection mechanisms which influenced migration flows between Ireland and England in the $20^{\text {th }}$ century. Higher migration costs will generally require higher levels of human capital $k_{\text {ih }}$ to justify migration. Since health is an important form of human capital, this is the main theoretical cost justification of the healthy migrant effect. Since monetary costs of migration from Ireland to England were very low historically (basically free migration with very low transportation costs), this implies that compared to Irish migrants to America, Canada, Australia, and New Zealand, Irish migrants to England will be less positively selected on skills and health.

Unless migration costs are negative, any parameter that lowers the size of the term in parenthesis is equation (6) implies that migrants must be more skilled to justify the migration 
since it will take more skilled migrants to offset migration costs. For example, the lower the uniform wage premium $\left(\beta_{0}\right)$ of the receiving to sending country the more skilled and healthy migrants relative to the average skill and health in the sending country will be. Thus, as income differences between the two countries become smaller, this model predicts that Irish migrants will become more positively selective. We will test this implication in the next section. The greater the wage skill premium $\left(\beta_{H}\right)$ in the receiving country relative to the sending country the more negative migration selection. While migration rates will increase if skill or work transferability is high, the migrants who come will be less skilled and less healthy.

We now consider how well our model predicts the $20^{\text {th }}$ century patterns of Irish emigration to England. Historical and geographical links between Ireland and England holds vital explanatory power. Our context is low relative costs (dis-utilities) of migration, $\theta_{i}$, and high levels of human capital and skill utilization transferability, $\alpha_{H}$ and $c_{H}$. Physical transport costs between the two states are low due to geographical proximity. It is plausible to assume low psychic costs on average, based on lower costs of returns to Ireland, institutional and cultural similarities including a common language. High skill transferability between the two states is facilitated by the ease a which an individual can enter the labor market - no visa or permit is required. Thus, we see less selectivity amongst the Irish migrating to England resulting in lower average migrant skill levels. Indeed, a cross-country comparison of Irish migration destinations would be sufficient to illustrate how the correlation between relaxed selectivity and skill levels.

There was a significant improvement in the profile of Irish migrant cohorts in the $20^{\text {th }}$ century. Without any dramatic changes in migration costs or skill transferability our model predicts that this change was driven by an increase in Irish wage rates, $\beta_{H}$. During the latter part of the $20^{\text {th }}$ century Ireland experienced rapid economic growth relative to England. A buoyant 
Irish labor market halted net outflows of migrants and those who choose to migrate were more likely to have more schooling. Our model provides a simple explanation of the individual heterogeneous selection mechanisms characterizing Anglo-Irish migration in the $20^{\text {th }}$ century.

Psychic costs associated with location are usually not emphasized in economic migration models. It is generally thought in economic models of migration that psychic costs of migration are positive since the migrant is moving to a less familiar environment away from family and friends. However, for some potential migrants, there actually may be a high psychic cost of staying in the original environment. Those who suffered some mental distress as children or young adults associated with their family life or school life in Ireland may feel less mental distress away from the country environment associated with the origins of these problems. We show below that this situation actually characterize a meaningful fraction of Irish migrants to England. If so, in our model for such people the costs of migration to England could actually be negative which would increasingly select less skilled and less healthy Irish migrants.

\subsection{Empirical Selection Results}

In this section, we summarize results obtained for our model of immigrant selection among Irish migrants in England. Column 1 in Table 3 displays results of our education selection model while column 2 does the same for height. In these selection models, we include on the right hand side mean gender specific education or height of the Irish cohort in which you were born as education and height will move with trends in Ireland and our issue concerns selection relative to these trends. Our main selection drivers are real income differences and unemployment rates differences between Ireland and England in year of migration and the extent of violence measured by number of deaths due to Irish political violence in Britain in the migration year. 
Table 3. Selection Models of Irish Migrant Height and Education

\begin{tabular}{lcc}
\hline & $(1)$ & $(2)$ \\
Variables & Ed in years & Height in cm \\
\hline Male & -0.123 & $12.25^{* * *}$ \\
& $(0.367)$ & $(0.789)$ \\
Real difference in ln wages & $5.194^{* * *}$ & $7.586^{* *}$ \\
& $(1.861)$ & $(3.507)$ \\
Unemployment Differences & -0.065 & 0.024 \\
& $(0.066)$ & $(0.141)$ \\
Political Violence & -0.003 & -0.004 \\
& $(0.002)$ & $(0.005)$ \\
Irish Education Matched Cohort Year & $0.584^{* *}$ & $\mathrm{NA}$ \\
& $(0.297)$ & $\mathrm{NA}$ \\
Irish Height Matched Cohort Year & $\mathrm{NA}$ & $0.706^{* *}$ \\
& $\mathrm{NA}$ & $(0.340)$ \\
Constant & $6.018^{*}$ & 43.39 \\
& $(3.602)$ & $(58.13)$ \\
Observations & 287 & 278 \\
R-squared & 0.148 & 0.499 \\
\hline
\end{tabular}

Standard errors in parentheses. Sample Irish in England

${ }^{* * *} \mathrm{p}<0.01,{ }^{* *} \mathrm{p}<0.05,{ }^{*} \mathrm{p}<0.1$.

Not surprisingly, education levels and height in Ireland are highly predictive of the education and height of the Irish born living in England for the same cohort reflecting the fact that as education levels and height improved in Ireland throughout the latter half of the 20th century, so too did education and height of migrants travelling to England. Differences in unemployment rates between the two countries and our measure of political violence do not influence the education or height of migrants travelling to England. However, differences in log real-wages at the time of migration have a statistically significant and quantitatively meaningful effect on education of Irish migrants in England. This result is consistent with our model of migrant selection since as wage differences converge, migrants should be more skilled relative to the sending country mean. We performed the same analysis using height as the selection variable. Again, the real wage gap between Britain and Ireland is highly predictive so that the higher wages in Ireland relative to England, the taller a migrant for that migration cohort will be. When we conducted separate analysis by gender, the impact of real wage differences of education of Irish migrants was more than twice as high for men compared to women. Greater 
selectively for men compared to women is as expected given that on average male migration is more focused on labor market reasons than is that of women.

These selection effects are strong, given the rapid convergence of Irish real wages to English real wages over the time period. Real wages at the start of the period is log -0.5 lower in Ireland and converges fully over the time period. So this alone would predict a 1.25 years contraction of the difference in education out relative to an unadjusted difference of 1.5 years, controlling for changes in base education in Ireland and a contraction of 2.4 centimeters in the height difference out of 2.8 centimeter unadjusted contraction over this time period, controlling for base levels of education in Ireland.

\subsection{Assimilation, Selection, and Psychological Health}

As well as negative migrant selection, the possibility that the Irish in England are less healthy both in physical and mental health due to a stressful process of assimilating into a foreign country must be considered. The migration process is often viewed as stressful and life in a different land can add to that stress. While transport costs were low, political tensions were high during much of the $20^{\text {th }}$ century, particularly during the 1970 s and 1980s, when the conflict surrounding Northern Ireland was at a peak. While we found no evidence above that political violence influenced selection of Irish migrants, it is possible that a cumulative impact of living in England during those years carried with it a physical and mental health cost for Irish migrants.

Our data permit tests of the assimilation hypothesis as a reason for the negative health disadvantage of Irish migrants to England. The ethnic booster samples of HSE ask migrants at what age they migrated to England. If exposure to an English environment is leading to stress and a greater propensity to adopt unhealthy behavior patterns, this should intensify with more years of exposure to this environment. There is significant heterogeneity in the amount of time 
since migration among Irish migrants in England even within different age cohorts that acts as an indicator of "exposure" to an English environment.

In this section, we first test whether this duration of exposure has large implications for the health conditions and health behaviors of the Irish migrant group. To examine this, we include time since migration into models of good health, GHQ score, the probability of marriage and smoking and drinking behavior. These models also include our two markers for selection effects- respondents' years of schooling and height relative to their birth cohort means. The height indicator is gender specific. The results are displayed in Table 4.

\section{Table 4: Health and Behaviors of Irish by Years Spent in England}

\begin{tabular}{|c|c|c|c|c|c|c|}
\hline Variables & (1) & good & GHQ score & smoker & married & $\begin{array}{c}\text { (8) } \\
\text { Amount of } \\
\text { drinks }\end{array}$ \\
\hline \multicolumn{7}{|l|}{$\begin{array}{l}\text { Education diff } \\
\text { relative to birth }\end{array}$} \\
\hline cohort mean & $-0.0126 * *$ & $0.0282 * * *$ & $-0.247 * *$ & -0.0048 & 0.0002 & -0.113 \\
\hline & $(0.0053)$ & $(0.0074)$ & $(0.0958)$ & $(0.0076)$ & $(0.0081)$ & $(0.554)$ \\
\hline \multicolumn{7}{|l|}{ Height diff relative to } \\
\hline \multirow[t]{2}{*}{ birth cohort mean } & 0.00057 & 0.0004 & 0.0013 & -0.0004 & $0.0119 * * *$ & -0.281 \\
\hline & $(0.0024)$ & $(0.0034)$ & $(0.0435)$ & $(0.0034)$ & $(0.0037)$ & $(0.231)$ \\
\hline \multirow[t]{2}{*}{ male } & $0.0749 *$ & $-0.104 *$ & -0.158 & $0.193 * * *$ & -0.0994 & $20.09 * * *$ \\
\hline & $(0.0430)$ & $(0.0607)$ & $(0.728)$ & $(0.0616)$ & $(0.0660)$ & (4.337) \\
\hline \multirow[t]{2}{*}{ Years since migration } & 0.0019 & 0.0007 & 0.0610 & -0.0009 & 0.0005 & 0.227 \\
\hline & $(0.0025)$ & $(0.0035)$ & $(0.0405)$ & $(0.0036)$ & $(0.0039)$ & $(0.252)$ \\
\hline \multirow[t]{2}{*}{ Born 1921-30 } & 0.0943 & $-0.179 *$ & 1.234 & 0.0982 & $0.205^{*}$ & 4.555 \\
\hline & $(0.0732)$ & $(0.103)$ & (1.041) & $(0.105)$ & $(0.112)$ & $(6.151)$ \\
\hline \multirow[t]{2}{*}{ Born 1931-40 } & 0.125 & $-0.181^{*}$ & $3.495^{* * *}$ & 0.0843 & $0.303 * *$ & 6.212 \\
\hline & $(0.0776)$ & $(0.109)$ & (1.143) & $(0.111)$ & $(0.119)$ & (6.918) \\
\hline \multirow[t]{2}{*}{ Born 1941-50 } & 0.0983 & -0.0851 & $3.670 * * *$ & 0.112 & $0.323 * *$ & $15.73^{*}$ \\
\hline & (0.0898) & $(0.127)$ & (1.361) & $(0.129)$ & $(0.138)$ & (8.377) \\
\hline \multirow[t]{2}{*}{ Born 1951-60 } & 0.103 & 0.0760 & $5.594 * * *$ & 0.108 & $0.381 * *$ & 16.28 \\
\hline & $(0.114)$ & $(0.161)$ & (1.743) & $(0.163)$ & $(0.175)$ & (10.97) \\
\hline \multirow[t]{2}{*}{ Born 1961-70 } & 0.0195 & 0.261 & $3.595 *$ & 0.0415 & $0.398^{*}$ & 18.16 \\
\hline & $(0.136)$ & $(0.192)$ & (2.045) & $(0.195)$ & $(0.209)$ & (13.27) \\
\hline \multirow[t]{2}{*}{ Born 1971-80 } & 0.0474 & 0.235 & $5.850 * *$ & -0.111 & 0.0155 & 21.07 \\
\hline & $(0.153)$ & $(0.216)$ & $(2.374)$ & $(0.219)$ & $(0.235)$ & (15.04) \\
\hline \multirow[t]{2}{*}{ Constant } & -0.0635 & $0.694 * * *$ & $5.333 * *$ & $0.588 * *$ & 0.358 & -17.70 \\
\hline & $(0.162)$ & $(0.229)$ & $(2.570)$ & $(0.232)$ & $(0.249)$ & $(16.02)$ \\
\hline Observations & 457 & 457 & 420 & 457 & 457 & 242 \\
\hline R-squared & 0.070 & 0.168 & 0.059 & 0.060 & 0.091 & 0.140 \\
\hline
\end{tabular}

Standard errors in parentheses. Sample Irish in England

*** $\mathrm{p}<0.01, * * \mathrm{p}<0.05, * \mathrm{p}<0.1$. 
Controlling for migration selection effects and birth cohort dummies, Table 4 shows that length of time spent in England does not predict any of these outcomes. This is despite the fact that there is heterogeneity in the length of time each birth cohort has spent in England. In part, this result may be due to relatively small sizes of the Irish in England available in English surveys, but the size of the estimated effects look small as well.

A closer look at birth cohort differences in some relevant behavioral outcomes of Irish migrants compared to White English and the Irish in Ireland is contained in Table 5. In terms of marriage for both men and women, the Irish in England are less likely to be currently married, are more likely to be divorced or separated, and are much more likely especially in the older cohorts to be widowed. High rates of widowhood are a vivid indicator of the poor health of these Irish migrants to England while the high rates of marital instability may reflect the psychological problems these migrants faced.

Irish migrants are characterized by very high rates of ever smoking, but their current smoking is more in line with the other two groups indicating high rates of smoking cessation, most likely due to health reasons. Most smoking was initiated prior to migration. If we compare age of migration and age one started to smoke among Irish migrants in the HSE, 68 \% started smoking pre-migration and more than half of these were at least five years before-migration. Finally, compared to the White English, among those who drink Irish migrants are heavy drinkers, but a much larger fraction of Irish migrants have stopped consuming alcohol, a likely indicator of problem drinking (no drinking variables are in the Living in Ireland Survey). 


\section{Table 5. Health Behaviors of the Three Groups}

\section{Male Behaviors}

\begin{tabular}{|c|c|c|c|c|c|c|c|c|c|}
\hline \multirow[b]{2}{*}{ Birth cohort } & \multicolumn{3}{|c|}{ Currently Married } & \multicolumn{3}{|c|}{ Divorced or Separated } & \multicolumn{3}{|c|}{ Widowed } \\
\hline & $\begin{array}{l}\text { Irish in } \\
\text { England }\end{array}$ & $\begin{array}{l}\text { Irish in } \\
\text { Ireland }\end{array}$ & $\begin{array}{l}\text { White } \\
\text { English }\end{array}$ & $\begin{array}{l}\text { Irish in } \\
\text { England }\end{array}$ & $\begin{array}{l}\text { Irish in } \\
\text { Ireland }\end{array}$ & $\begin{array}{l}\text { White } \\
\text { English }\end{array}$ & $\begin{array}{l}\text { Irish in } \\
\text { England }\end{array}$ & $\begin{array}{l}\text { Irish in } \\
\text { Ireland }\end{array}$ & $\begin{array}{l}\text { White } \\
\text { English }\end{array}$ \\
\hline Pre-1921 & 0.538 & 0.578 & 0.604 & 0.000 & 0.000 & 0.019 & 0.423 & 0.207 & 0.353 \\
\hline 1921-1930 & 0.517 & 0.788 & 0.766 & 0.109 & 0.010 & 0.034 & 0.273 & 0.067 & 0.142 \\
\hline 1931-1940 & 0.605 & 0.805 & 0.824 & 0.154 & 0.024 & 0.079 & 0.103 & 0.041 & 0.039 \\
\hline 1941-1950 & 0.561 & 0.876 & 0.786 & 0.141 & 0.026 & 0.115 & 0.032 & 0.007 & 0.014 \\
\hline $1951-1960$ & 0.717 & 0.832 & 0.726 & 0.103 & 0.023 & 0.137 & 0.000 & 0.008 & 0.003 \\
\hline 1961-1970 & 0.550 & 0.578 & 0.557 & 0.063 & 0.009 & 0.092 & 0.000 & 0.000 & 0.002 \\
\hline 1971-1980 & 0.174 & 0.027 & 0.105 & 0.000 & 0.000 & 0.009 & 0.000 & 0.000 & 0.000 \\
\hline
\end{tabular}

\begin{tabular}{|c|c|c|c|c|c|c|c|c|c|c|}
\hline & \multicolumn{3}{|c|}{ Ever Smoked } & \multicolumn{3}{|c|}{ Currently Smoking } & \multicolumn{2}{|c|}{$\begin{array}{l}\text { Units of Alcohol } \\
\text { Among Drinkers }\end{array}$} & \multicolumn{2}{|c|}{$\begin{array}{c}\text { Fraction Who } \\
\text { Stopped Drinking }\end{array}$} \\
\hline Birth cohort & $\begin{array}{l}\text { Irish in } \\
\text { England }\end{array}$ & $\begin{array}{l}\text { Irish in } \\
\text { Ireland }\end{array}$ & $\begin{array}{l}\text { White } \\
\text { English }\end{array}$ & $\begin{array}{l}\text { Irish in } \\
\text { England }\end{array}$ & $\begin{array}{l}\text { Irish in } \\
\text { Ireland }\end{array}$ & $\begin{array}{l}\text { White } \\
\text { English }\end{array}$ & $\begin{array}{l}\text { Irish in } \\
\text { England }\end{array}$ & $\begin{array}{l}\text { White } \\
\text { English }\end{array}$ & $\begin{array}{l}\text { Irish in } \\
\text { England }\end{array}$ & $\begin{array}{l}\text { White } \\
\text { English }\end{array}$ \\
\hline Pre-1921 & 0.692 & 0.664 & 0.751 & 0.077 & 0.328 & 0.080 & 11.05 & 9.65 & 0.192 & 0.096 \\
\hline 1921-1930 & 0.845 & 0.580 & 0.803 & 0.200 & 0.234 & 0.166 & 16.46 & 13.12 & 0.091 & 0.072 \\
\hline $1931-1940$ & 0.815 & 0.607 & 0.731 & 0.231 & 0.265 & 0.216 & 18.35 & 14.89 & 0.154 & 0.046 \\
\hline 1941-1950 & 0.805 & 0.547 & 0.734 & 0.375 & 0.278 & 0.273 & 28.35 & 21.96 & 0.141 & 0.032 \\
\hline $1951-1960$ & 0.792 & 0.490 & 0.603 & 0.436 & 0.316 & 0.317 & 22.10 & 21.44 & 0.103 & 0.021 \\
\hline $1961-1970$ & 0.750 & 0.474 & 0.558 & 0.438 & 0.374 & 0.346 & 31.82 & 21.10 & 0.000 & 0.021 \\
\hline 1971-1980 & 0.435 & 0.412 & 0.590 & 0.158 & 0.342 & 0.454 & 40.18 & 27.51 & 0.053 & 0.019 \\
\hline
\end{tabular}

Female Behaviors

\begin{tabular}{lcccccccccc}
\hline & \multicolumn{3}{c}{ Currently Married } & \multicolumn{3}{c}{ Divorced or Separated } & \multicolumn{3}{c}{ Widowed } \\
& $\begin{array}{c}\text { Irish in } \\
\text { Birth cohort }\end{array}$ & $\begin{array}{c}\text { Irish in } \\
\text { England }\end{array}$ & $\begin{array}{c}\text { White } \\
\text { Ireland }\end{array}$ & $\begin{array}{c}\text { Irish in } \\
\text { English }\end{array}$ & $\begin{array}{c}\text { Irish in } \\
\text { England }\end{array}$ & $\begin{array}{c}\text { White } \\
\text { Ireland } \\
\text { English }\end{array}$ & $\begin{array}{c}\text { Irish in } \\
\text { England }\end{array}$ & $\begin{array}{c}\text { Irish in } \\
\text { Ireland }\end{array}$ & $\begin{array}{c}\text { White } \\
\text { English }\end{array}$ \\
\hline Pre-1921 & 0.192 & 0.248 & 0.237 & 0.080 & 0.007 & 0.023 & 0.680 & 0.669 & 0.671 \\
$1921-1930$ & 0.421 & 0.575 & 0.490 & 0.042 & 0.006 & 0.055 & 0.465 & 0.343 & 0.394 \\
$1931-1940$ & 0.543 & 0.789 & 0.699 & 0.140 & 0.016 & 0.100 & 0.333 & 0.148 & 0.161 \\
$1941-1950$ & 0.642 & 0.848 & 0.740 & 0.214 & 0.055 & 0.174 & 0.095 & 0.049 & 0.037 \\
$1951-1960$ & 0.614 & 0.871 & 0.717 & 0.231 & 0.055 & 0.196 & 0.019 & 0.007 & 0.013 \\
$1961-1970$ & 0.607 & 0.716 & 0.589 & 0.080 & 0.037 & 0.153 & 0.000 & 0.007 & 0.003 \\
$1971-1980$ & 0.209 & 0.085 & 0.190 & 0.000 & 0.005 & 0.036 & 0.000 & 0.000 & 0.001 \\
\hline
\end{tabular}




\begin{tabular}{|c|c|c|c|c|c|c|c|c|c|c|}
\hline \multirow[b]{2}{*}{ Birth cohort } & \multicolumn{3}{|c|}{ Ever Smoked } & \multicolumn{3}{|c|}{ Currently Smoking } & \multicolumn{2}{|c|}{$\begin{array}{l}\text { Units of Alcohol } \\
\text { Among Drinkers }\end{array}$} & \multicolumn{2}{|c|}{$\begin{array}{l}\text { Fraction Who } \\
\text { Stopped Drinking }\end{array}$} \\
\hline & $\begin{array}{l}\text { Irish in } \\
\text { England }\end{array}$ & $\begin{array}{l}\text { Irish in } \\
\text { Ireland }\end{array}$ & $\begin{array}{l}\text { White } \\
\text { English }\end{array}$ & $\begin{array}{l}\text { Irish in } \\
\text { England }\end{array}$ & $\begin{array}{l}\text { Irish in } \\
\text { Ireland }\end{array}$ & $\begin{array}{l}\text { White } \\
\text { English }\end{array}$ & $\begin{array}{l}\text { Irish in } \\
\text { England }\end{array}$ & $\begin{array}{l}\text { White } \\
\text { English }\end{array}$ & $\begin{array}{l}\text { Irish in } \\
\text { England }\end{array}$ & $\begin{array}{l}\text { White } \\
\text { English }\end{array}$ \\
\hline Pre-1921 & 0.654 & 0.297 & 0.481 & 0.120 & 0.090 & 0.089 & 3.73 & 4.40 & 0.000 & 0.113 \\
\hline $1921-1930$ & 0.645 & 0.370 & 0.602 & 0.225 & 0.196 & 0.154 & 4.79 & 5.48 & 0.127 & 0.094 \\
\hline $1931-1940$ & 0.629 & 0.417 & 0.592 & 0.258 & 0.233 & 0.255 & 3.50 & 6.15 & 0.108 & 0.053 \\
\hline $1941-1950$ & 0.642 & 0.411 & 0.562 & 0.238 & 0.250 & 0.275 & 5.19 & 8.24 & 0.083 & 0.038 \\
\hline $1951-1960$ & 0.614 & 0.445 & 0.570 & 0.423 & 0.272 & 0.288 & 7.38 & 9.01 & 0.058 & 0.032 \\
\hline $1961-1970$ & 0.607 & 0.479 & 0.552 & 0.380 & 0.369 & 0.345 & 7.23 & 8.95 & 0.120 & 0.029 \\
\hline 1971-1980 & 0.674 & 0.416 & 0.582 & 0.436 & 0.353 & 0.408 & 14.21 & 12.49 & 0.051 & 0.025 \\
\hline
\end{tabular}

\subsection{Pre-Migration Psychological Health}

If the evidence that poor physical and mental health was primarily due to conditions in England is weak, what can account for greater health problems among Irish migrants? A strong possibility suggested by our theoretical model is that factors that led to poor mental health in Ireland increased the propensity to migrate. What is the evidence on pre-migration mental health? One explanation comes from investigating abuse in industrial or reformatory schools in Ireland (schools for children with excess truancy, involvement in crime, or where families were deemed incapable of caring for children). The Ryan Commission interviewed over 1,200 people who attended these schools and over 30\% were currently living in the UK. 30\% is most likely a lower bound for those who migrated, given the greater difficulty in tracking people down who migrated to another country. An estimate that the Commission employed was that approximately $50 \%$ of the children who attended these schools migrated. ${ }^{6}$

To get a sense of the scale, the Commission estimated that approximately 100,000 people during the years 1930-1970 attended these schools. ${ }^{7}$ Based on net migration flows in Fig.1 and a

\footnotetext{
${ }^{6}$ For full details, see documentation on the Ryan Commission website.. http://www.childabusecommission.ie/

7 Volume 1 chapter 3 of the Commission Report for a detailed description of numbers and reasons for admission.
} 
$.80 \%$ migration to the UK, we estimate a net migration of 790,000 Irish to England between 1927 and 1970. Attendees of these schools would then represent $6.3 \%$ of these migrants.

Pre-migration mental problems of Irish migrants to England are not limited to issues associated with this group of schools. Other evidence rests on abuse and neglect of children in $20^{\text {th }}$ century Ireland shaping the migrant health trajectories in England. The 2002 SAVI report based on telephone interviews with over 3,000 people in Ireland revealed high rates of childhood abuse incidents among men and women. 20.4\% of female respondents reported contact sexual abuse as children and $10 \%$ reported non-contact abuse, with $5.4 \%$ reporting penetrative sexual abuse. For men, $16.2 \%$ reported contact sexual abuse as children and $7.4 \%$ non-contact abuse, with $2.7 \%$ of men reporting penetrative sexual abuse as children. In total, almost a third of women and a quarter of men reported some form of sexual abuse as children.

Forty percent of these cases involved multiple abuses rather than a single instance. For girls, $24 \%$ of perpetrators were family members, $24 \%$ strangers and $52 \%$ non-family known to the girl. For boys, $14 \%$ of perpetrators were family members, half were non-family known to the child and a fifth were strangers. Of the group abused, about a third of women and a quarter of men reported moderate or extreme effects on their adult lives, with a quarter of women and $16 \%$ of men reporting symptoms consistent with Post-Traumatic-Stress Disorder. The abusive environment many potential migrants experienced at home, combined with better wages in England, suggests that such abusive environments may have effects on dynamics of migrant health in England.

Several epidemiological studies support the idea that pre-migration factors were operating in setting mental health of Irish migrants into the UK. Ryan et al. (2006), using data from a case-control study of 360 Irish people sampled in primary care settings, find that men 
with pre-migration mental health conditions were seven times more likely to have an existing psychological problem. Such effects exist for women but to a much smaller degree (1.6 times more likely), something supported in our HSE analysis. Ryan et al. (op cit) report that $40 \%$ of the Irish migrants in their depressed Irish migrant cohort reported experiencing some degree of emotional abuse and neglect before they came to England during their childhood in Ireland.

Cochrane and Bal (1989) report higher rates of admission to psychiatric institutions for a range of conditions of Irish migrants in both 1971 and 1981. Once again contradicting an exclusive assimilation story, while Irish rates are higher than other groups in both 1971 and 1981, the rates of admission among Irish migrants subsequently declines, consistent with a steady improvement in overall health of the birth cohorts entering England. Raleigh et al. (1992) report that young (ages 20-29) Irish migrants in England and Wales in 1979-1983 had relative suicide rates of 174 for women and 267 for men (compared to general population of 100).

The potential that the Irish migrant health disadvantage has it roots in childhood and adolescent conditions in Ireland more so than post-migration factors in England is given credence by a wide variety of evidence. Evident from our own analysis, the migrants clearly have lower education levels and are shorter in stature than both their birth cohort in Ireland and the White English group. Furthermore, the excess smoking rate is poorly explained by assimilation to that of the English population as their smoking rate is higher than both the Irish population and the English population and, crucially, the majority of smokers started prior to migration. The lack of predictive power of time since migration is also strongly suggestive of a limited role of post-migration stress in generating the observed differences.

Another possibility our findings raise is that the Irish of this generation were not only not harmed by going to England but possibly helped. It is well-documented that NHS mental and 
physical health services were of far higher quality than those in Ireland over this period, and were utilized highly by the Irish migrant group. Many people interviewed in the Ryan Report speak favorably and spontaneously about their treatment in the English public health system.

\section{Conclusions}

The heterogeneous pattern of health conditions of Irish migrants in England is driven in large part by selection factors. As well as being less healthy, the Irish born in the birth cohorts most affected by migration selection are shorter and less educated, even when we exclude those who came to England as children. These patterns fit a model whereby more educated people relative to the birth cohort mean enter into England when the relative wages between England and Ireland narrow. As the economy improved in Ireland in the last quarter of the twentieth century, positive selection characterized the process of migration from Ireland to England.

Furthermore, rates of psychological distress among Irish migrants are high and appear to be strongly related to pre-migration conditions in Ireland and less related to the length of time spent in the UK, as would be expected if exposure to the UK environment was primarily generating health differences. The patterns revealed by combining all the evidence in this paper are compelling that a simple assimilation story by itself is insufficient in explaining Irish migrant health patterns. Migrants born in the 30s, 40s and 50s and 60s brought with them to England lower education and shorter stature and they subsequently had worse health. 


\section{References}

Adelstein A, Marmot M, Dean G, Bradshaw JS. Comparison of mortality of Irish immigrants in England and Wales with that of Irish and British nationals. Irish Medical Journal 1986; 79(7); 185-189.

Aspinall PJ. Suicide amongst Irish migrants in Britain: A review of the identity and integration hypothesis. International Journal of Social Psychiatry 2002; 48(4); 290-304.

Cochrane R. The social creation of mental illness. London: Longman; 1983.

Cochrane R, Bal S. Mental hospital admission rates of immigrants to England: A comparison of 1971 and 1981. Social Psychiatry and Psychiatric Epidemiology 1989; 24; 2-11.

Delaney L, O'hAodha F, Wall, P. Social capital and self-rated health in the Republic of Ireland: Evidence from the European Social Survey. Irish Medical Journal 2007; 100(8); 52-55.

Goldberg DP, Blackwell B. Psychiatric illness in general practice: A detailed study using a new method of case identification. British Medical Journal 1970; 1; 439-443.

Hannan D. Rural exodus: A study of the forces influencing the large-scale migration of Irish rural youth. G. Chapman: London; 1970.

Harding S, Maxwell R. Differences in mortality of migrants. In: Drever F, Whitehead M (Eds), Health inequalities: Decennial supplement. Office for National Statistics HMSO: London; 1997. p. 108-121.

Jasso G, Massey D, Rosenzweig M, Smith JP. Immigration health: Selectivity and acculturation. In: Anderson NB, Bulatao RA, Cohen B (Eds.), Critical perspectives on racial and ethnic differences in health in late life. National Academies Press: Washington DC; 2004. p. 227-266.

Kearney I. Is there a stable migration equation for Ireland? ESRI Working Paper WP097. 
Economic and Social Research Institute (ESRI): Dublin; 1998.

Leavey G. Suicide and Irish migrants in Britain: Identity and integration. International Review of Psychiatry 1999; 11(2-3); 168-172.

Leavey G, Rozmovits L, Ryan L, King M. Explanations of depression among Irish migrants in Britain. Social Science \& Medicine 2006; 65(2); 231-244.

Marmot M, Adelstein A, Bulusu L. Immigrant mortality in England and Wales: 1970-1978. OPCS Studies on Population and Medical Subjects No. 47. London, Office of Population Censuses and Surveys, OPCS: London; 1984.

McGee H, Garavan R, De Barra M, Byrne J, Conroy R. The SAVI Report: Sexual abuse and violence in Ireland. Liffey Press: Dublin; 2002.

National and Economic and Social Council (NESC). The economic and social implications of emigration. Prepared for the Council by Sexton G, Hannan DF, Walsh BM, McMahon D. National Economic and Social Council: Dublin; 1991.

O'Grada C, Walsh BM. The economic effects of emigration: Ireland. In: Asch BJ (Ed), Emigration and its effects on the sending country. The RAND Corporation: Santa Monica, California; 1994. p. 97-141.

Office of Population Censuses and Surveys (OPCS). Mortality and geography: A review in the mid 1980s. Series DS no. 9. HMSO: London; 1990.

Raftery J, Jones, DR, Rosato M. The mortality of first and second generation Irish immigrants in the UK. Social Science and Medicine 1990; 31(5); 577-584.

Raleigh VS, Balarajan R. Suicide levels and trends among immigrants in England and Wales. Health Trends 1992; 24; 91-94. 


\section{Appendix Table 1: Educational Attainment Decomposition}

\begin{tabular}{cc}
\hline Age Finished Full-Time Education & Number of Years Schooling \\
\hline Not yet finished & N/A \\
Never went to school & 0 \\
14 or under & 7 \\
15 & 10 \\
16 & 11 \\
17 & 12 \\
18 & 13 \\
19 or over & 16 \\
\hline
\end{tabular}

\section{Appendix Table 2. Educational Attainment Decomposition,}

Living in Ireland

\begin{tabular}{lcc}
\hline Highest level of education completed & Freq. & Eduyrs \\
\hline No_ed & 896 & 0 \\
Primary & 806 & 7 \\
Some_Sec & 640 & 9 \\
Group & 436 & 10 \\
Inter & 839 & 10 \\
Junior & 530 & 10 \\
Leaving & 2,135 & 12 \\
VPT_PLC & 251 & 13 \\
Dip_RTC & 567 & 14 \\
Prim_Deg & 508 & 16 \\
High_Deg & 241 & 16 \\
\hline
\end{tabular}

